\title{
Detecting herpesvirus DNA in uveitis using the polymerase chain reaction
}

\author{
Shuji Yamamoto, Deborah Pavan-Langston, Shigeru Kinoshita, Kohji Nishida, \\ Yoshikazu Shimomura, Yasuo Tano
}

\begin{abstract}
Background-Herpesviruses are involved in the pathogenesis of many ocular diseases including keratitis, iridocyclitis, and acute retinal necrosis syndrome. The rapid and accurate diagnosis of herpetic infections has become increasingly important with the rising incidence of immunosuppressive diseases. The purpose of this study was to evaluate the use of the polymerase chain reaction (PCR) to detect herpesvirus DNA in uveitis patients.
\end{abstract}

Methods-Aqueous samples were aspirated from 11 patients with active uveitis of suspected viral origin. Using PCR, masked samples were assayed for herpes simplex virus (HSV), varicella zoster virus (VZV), and cytomegalovirus (CMV) to assist in supporting the clinical diagnosis of viral aetiology. Masked controls included 10 aqueous humour specimens from normal patients undergoing cataract surgery and specimens from seven patients diagnosed with active non-viral uveitis - Behçet's disease, sarcoidosis, Fuchs' heterochromic iridocyclitis, or Harada's disease.

Results-Ten of 11 cases clinically diagnosed as being of possible viral aetiology yielded aqueous PCR positive for a herpesvirus. Eight patients were PCR positive for amplified HSV DNA, of whom two had acute retinal necrosis, one had corneal endotheliitis, and five had recurrent iridocyclitis. VZV DNA was detected in one case of iridocyclitis, and CMV DNA in one case of chorioretinitis. Successful therapy was based on the PCR results. Ten normal aqueous specimens and the seven uveitis samples from cases not suspected of a viral aetiology were PCR negative for HSV, VZV, and CMV.

Conclusion-These results demonstrate that detecting herpesvirus DNA in the aqueous humour is useful to support a clinical diagnosis of viral uveitis.

(Br F Ophthalmol 1996; 80: 465-468)

Osaka University Medical School, Osaka, Japan $S$ Yamamoto Y Shimomura Y Tano

Correspondence to: Shuii Yamamoto, MD Department of Department of Ophthalmology, Osaka University Medical Schoo 2-2, Yamada-oka, Suita Osaka, 565, Japan.

Accepted for publication 18 January 1996 wes, including herpes simplex (HSV), varicella zoster virus (VZV), and cytomegalovirus (CMV) are involved in the pathogenesis of many ocular diseases including keratitis, iridocyclitis, acute retinal necrosis (ARN) syndrome, and chorioretinitis. ${ }^{1-8}$ Although HSV and VZV have long been regarded as principal aetiological agents in iridocyclitis, diagnosing viral iridocyclitis without previous keratitis or dermatitis is still difficult. ${ }^{1-3}$ The rapid and accurate diagnosis of herpetic infections has become increasingly important with the rising incidence of immunosuppressive diseases. ${ }^{9}$

Confirmation of a presumptive clinical diagnosis of herpetic infection may be done by viral isolation or serum antibody titres. Both require days to weeks for completion, thus delaying diagnosis and, therefore, therapy. ${ }^{78}$ Recently, the polymerase chain reaction (PCR), a highly sensitive and specific method, has been used in a variety of biomedical research studies including viral detection of many ocular inflammatory diseases. ${ }^{9-21}$ In the present study, we assayed for herpesvirus DNA (HSV, VZV, CMV) in aqueous humour specimens from patients with clinically suspected viral uveitis.

\section{Patients and methods}

Patients with various types of uveitis were selected from 180 consecutive cases of uveitis seen in the Department of Ophthalmology, Osaka University Medical School, Japan. Aqueous humour samples were obtained by paracentesis at the initial visit in 18 patients, 11 with anterior or posterior uveitis of suspected viral origin because of the recurrent nature and diffuse patchy iris atrophy, or corneal endotheliitis or ARN, and seven patients with active uveitis not suspected of having a viral aetiology (two cases each of Behçet's disease, sarcoidosis, Fuchs' heterochromic iridocyclitis, and one case of Harada's disease). Sera also were collected within 1 week of symptom onset and 2 weeks thereafter. Aqueous and serum specimens as routine controls were obtained from 10 patients who underwent routine cataract surgery.

DNA EXTRACTION AND PCR

Aqueous humour samples $(50 \mu \mathrm{l})$ were incubated at $55^{\circ} \mathrm{C}$ for 5 hours in a final reaction volume of $500 \mu \mathrm{l}$ containing $0.5 \%$ sodium dodecyl sulphate (SDS), $100 \mu \mathrm{g} / \mathrm{ml}$ of proteinase $\mathrm{K}, 1 \mathrm{mM}$ EDTA, and $10 \mathrm{mM}$ TRIS-

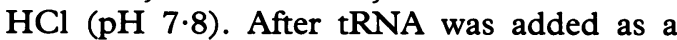
carrier, the solutions were extracted by phenol/chloroform, and DNA was precipitated with ethanol and dissolved in $10 \mu$ l of TRISEDTA buffer (10 mM TRIS- $\mathrm{HCl}$, pH 7.5, 1 mM EDTA). The concentration of DNA in each sample was determined by using spectrophotometric readings at a $260 \mathrm{~nm}$ wavelength. We used $0.1 \mu \mathrm{g}$ DNA as a template in all PCR 
Table 1 Primer and probe sequences

\begin{tabular}{|c|c|c|c|}
\hline $\mathrm{HSV}^{10-15}$ & $\begin{array}{l}5^{\prime} \text {-primer } \\
\text { 3'-primer } \\
\text { probe }\end{array}$ & $\begin{array}{l}\text { CATCACCGACCCGGAGAGGGAC } \\
\text { GGGCCAGGCGCTTGTTGGTGTA } \\
\text { GACTTTGTCCTCACCGCCGAACTGAGCAG }\end{array}$ & $92 \mathrm{bp}$ \\
\hline$V_{Z} V^{1617}$ & $\begin{array}{l}\text { 5'-primer } \\
\text { 3'-primer } \\
\text { probe }\end{array}$ & $\begin{array}{l}\text { TTCAGCCAACGTGCCAATAAA } \\
\text { GACGCGCTTAACGGAAGTAAC } \\
\text { TGAACAATCACGAACCGTTGACAGGACGTCAGATCACG }\end{array}$ & $642 b p$ \\
\hline $\mathrm{CMV}^{18}$ & $\begin{array}{l}5^{\prime} \text {-primer } \\
\text { 3'-primer } \\
\text { probe }\end{array}$ & $\begin{array}{l}\text { CACCTGTCACCGCTGCTATATTTGC } \\
\text { CACCACGCAGCGGCCCTTGATGTTT } \\
\text { GTCGCCTGCACTGCCAGGTGCTTCG }\end{array}$ & $0 \mathrm{bp}$ \\
\hline
\end{tabular}

$\mathrm{HSV}=$ herpes simplex virus; $\mathrm{VZV}=$ varicella zoster virus; $\mathrm{CMV}=$ cytomegalovirus; $\mathrm{bp}=$ base pair.

reactions. The PCR procedure was performed according to the method described by Saiki et al. ${ }^{21}$ The extracted DNA $(0 \cdot 1 \mu \mathrm{g})$ was subjected to PCR in $50 \mu$ l of PCR buffer $(10 \mathrm{mM}$ TRIS-HCl, $\mathrm{pH} 8.3,50 \mathrm{mM} \mathrm{KCl}, 1.5 \mathrm{mM}$ $\mathrm{MgCl}_{2}, 0.01 \%$ gelatin, $80 \mu \mathrm{M}$ each of all four triphosphates, 2.5 units of Taq polymerase, and $1 \mu \mathrm{mol}$ of each oligonucleotide primer). Reaction mixtures were prepared for multiple samples and aliquoted. The primers and probes used in this study (Table 1) were synthesised using an oligonucleotide synthesiser (Gene Assembler Plus; Pharmacia-LKB, Uppsala, Sweden). These primers are commonly used to amplify herpesvirus family genomes, and the specificity of the primers had been confirmed. For HSV amplification, primer pairs previously shown to identify a specific 92 base pair segment of the HSV DNA polymerase gene sequence were used. ${ }^{10-15}$ This specific nucleotide sequence exists in both HSV types 1 and 2. The primer pairs for VZV were used to amplify a 642 base pair target sequence that is incorporated in the EcoR1-D fragment of the varicella zoster virus genome. ${ }^{1617}$ We designed and synthesised 38 base pairs of oligonucleotide between sense and antisense primers and used them as probes. The primers used for CMV were the same as those used by Demmler et al. ${ }^{18}$ These primers allowed amplification of a 400 base pair sequence of CMV DNA that codes for a portion of a late antigen of CMV. ${ }^{18}$ Thirty two independent repeated cycles of the PCR reaction were done at $94^{\circ} \mathrm{C}$ for 1 minute, $55^{\circ} \mathrm{C}$ for 1 minute, and $72^{\circ} \mathrm{C}$ for 1 minute in a thermal cycler (Cetus, Perkin-Elmer, Norwalk, CT, USA).

\section{Results}

The clinical findings and the results of the PCR study are shown in Table 2 . Of the 11 cases of

Table 2 Clinical findings and polymerase chain reaction (PCR) results on patients with clinically suspected viral uveitis

\begin{tabular}{lllll}
\hline $\begin{array}{l}\text { Patient no/ } \\
\text { age (years)/ } \\
\text { sex }\end{array}$ & Clinical diagnosis/findings & \multicolumn{2}{l}{$P C R$ results } \\
\cline { 2 - 5 } & ASV VZV CMV \\
\hline 1/58/M & ARN & ++ & - & - \\
2/41/M & ARN & ++ & - & - \\
3/21/M & Iridocyclitis, KP, IOP increase, iris atrophy, recurrent episode & + & - & - \\
4/65/M & Iridocyclitis, KP, IOP increase, iris atrophy, recurrent episode & + & - & - \\
5/48/F & Iridocyclitis, KP, IOP increase, iris atrophy, recurrent episode & + & - & - \\
6/18/M & Iridocyclitis, KP, IOP increase, iris atrophy, recurrent episode & + & - & - \\
$7 / 54 / \mathrm{M}$ & Iridocyclitis, KP, IOP increase, iris atrophy, recurrent episode & + & - & - \\
8/4/F & Chorioretinitis, malignant lymphoma & - & - & + \\
9/72/F & Iridocyclitis, KP, IOP decrease, iris atrophy, recurrent episode & - & + & - \\
10/40/M & Corneal endotheliopathy, iridocyclitis & + & - & - \\
$11 / 21 / \mathrm{F}$ & ARN, 6 months after onset & - & - & -
\end{tabular}

$\mathrm{HSV}=$ herpes simplex virus; $\mathrm{VZV}=$ varicella zoster virus; $\mathrm{CMV}=$ cytomegalovirus; $\mathrm{ARN}=$ acute retinal necrosis; $K P=$ keratic precipitates; IOP=intraocular pressure. suspected viral uveitis studied, 10 were PCR positive for one herpesvirus (HSV, VZV, or CMV). Of the eight HSV-DNA positive patients, two had $\mathrm{ARN}$, one had corneal endotheliitis, and five had recurrent iridocyclitis. VZV DNA was detected in one case of iridocyclitis in a patient with pain in the $\mathrm{V}-1$ dermatome, and CMV DNA was detected in one case of chorioretinitis. The remaining seven uveitis samples (two cases each of Behçet's disease, Fuchs' heterochromic iridocyclitis, and sarcoidosis and one case of Harada's disease), and the 10 normal aqueous specimens were negative for HSV, VZV, and CMV.

Only one patient, an immunosuppressed female (case 8 , Table 2) had a marked increase in serum indirect immunofluorescent IgG antibody titres. This was against CMV (1:128, baseline; 1:2048, week 2), and was first demonstrable 2 weeks after symptom onset and our obtaining CMV positive PCR results. HSV $(1: 8 ; 1: 16)$ showed no notable change. The titre against VZV showed a notable fourfold increase ( $1: 8$, baseline; $1: 32$, week 2 ). It is possible, however, that high titres against VZV may reflect non-specific polyclonal activation of $B$ cells in an inflammatory process. For all other patients, serology was positive for all three herpesviruses (below 1:16), but the titres were insufficient to be diagnostically meaningful.

\section{CASE REPORT}

On 4 September 1991, a healthy 65-year-old man (case 4, Table 2) was referred to our clinic with iridocyclitis and glaucoma in the right eye unresponsive to treatment with topical steroids

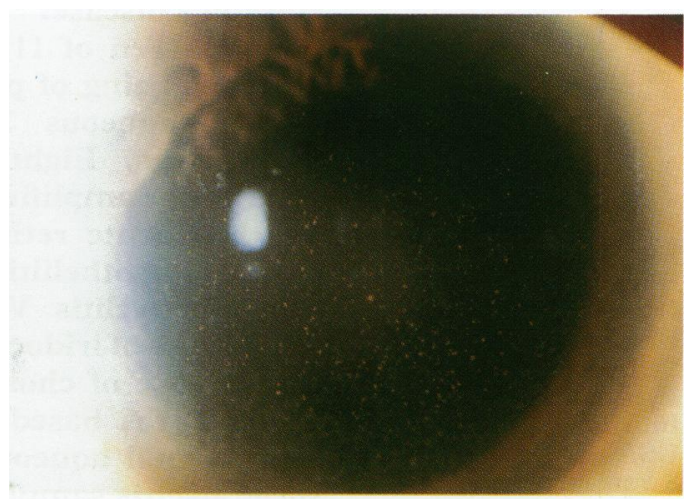

Fig $1 A$

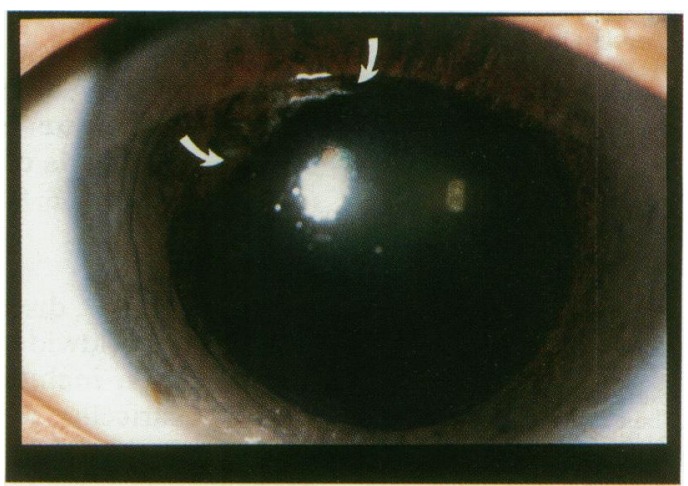

Fig $1 B$

Figure 1 (A) Numerous pigmented keratic precipitates are observed. (B) Posterior synechia and a small area of patchy iris atrophy are noted (arrows). 


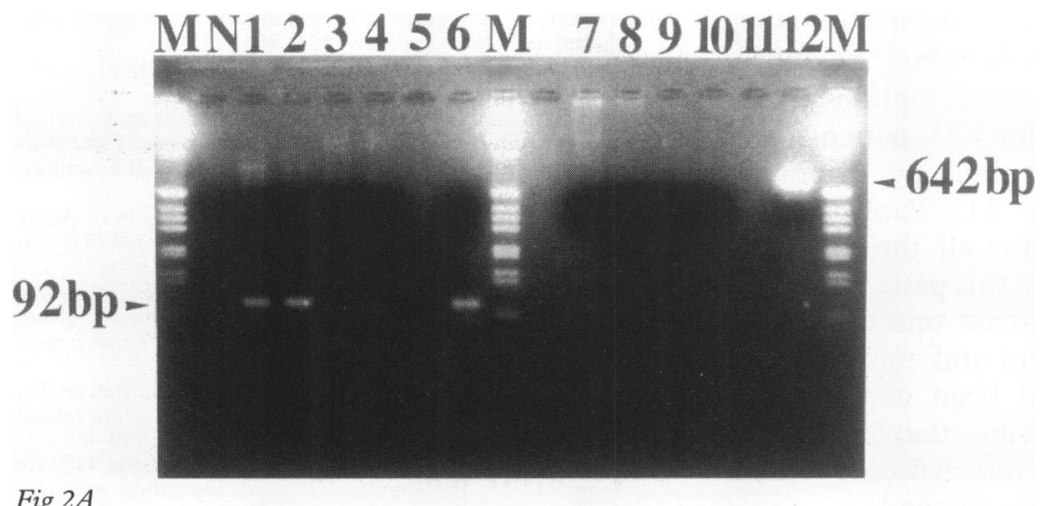

$123456 \quad 789101112$

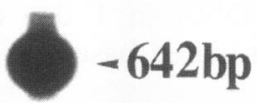

\section{2bp -

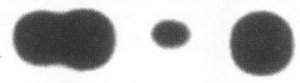 \\ Fig $2 B$}

Figure 2 (A) Gel electrophoresis profiles of polymerase chain reaction for herpes simplex virus (HSV) and varicella zoster virus (VZV). Lane M, $1 \mathrm{~kb}$ molecular weight standard (Gibco BRL). Lane $N$, negative control for the assay (no template added to the PCR reaction). Lanes 1-6, HSV; lanes 7-12,VZV; lanes 1 and 2, acute retinal necrosis $(A R N)$ (cases 1, 2); lanes 3 and 4, clinical uveitis (control patient with sarcoidosis, case 4, Table 2); lane 5, empty; lane 6, positive control for HSV DNA extracted from HSV virus stock; lanes 7 and 8, ARN patients (cases 1,2); lanes 9 and 10, clinical uveitis (control patient with sarcoidosis, case 4, Table 2); lane 11, empty; lane 12, positive control for VZV DNA extracted from VZV virus stock. (B) Southern blot hybridisation confirms the results. The lane orientations are the same as in $(A)$.

after 1 week. Ocular history revealed an anterior uveitis in the right eye with glaucoma 10 years previously. He was treated with a topical steroid and timolol eyedrops, and his condition resolved slowly over 2 months.

On 4 December 1991, he returned with recurrent iridocyclitis in the right eye, at which time his intraocular pressures (IOPs) were 29 and $15 \mathrm{~mm} \mathrm{Hg}$ in the right and left eyes, respectively. Slit-lamp examination showed numerous pigmented keratic precipitates (Fig 1A). Virus isolation on the aqueous aspirate on Vero cells was unsuccessful after a 4 week incubation at $37^{\circ} \mathrm{C}$. PCR results, available on the day of the first examination, were positive for HSV (Fig 2). On the basis of these results, we prescribed oral acyclovir $(200 \mathrm{mg}$ five times daily for 2 weeks), topical acyclovir $3 \%$ ointment five times daily, and a topical steroid $(0 \cdot 1 \%$ prednisolone) three times daily for 2 weeks. With this regimen, his condition resolved completely within 3 weeks (Fig 1B). There were no further recurrences during a 6 month follow up period.

\section{Discussion}

Herpetic ocular inflammatory disease is a problem encountered in both immunocompetent and immunosuppressed patients, but presents a greater diagnostic dilemma in the former group because of a low index of suspicion. Hence, the need for rapid and accurate diagnostic tools for herpetic infections. Accurate differentiation of HSV from VZV and CMV has significant therapeutic implications, because the agents for treating these diseases differ. $^{913}$ We previously reported the use of PCR to detect HSV DNA in tear specimens from patients with clinically diagnosed herpetic keratitis. ${ }^{12}$ In the present study, we assayed for herpesvirus DNA in aqueous humour specimens from patients with clinically suspected viral uveitis.

By using serial dilutions of cloned HSV and VZV DNA, amplification by our PCR allowed the detection of $1 \mathrm{fg}$ of DNA, equivalent to six or seven copies of $\mathrm{HSV}$ or VZV genomes. ${ }^{15}$ Even with this PCR sensitivity and specificity, no amplified HSV or VZV DNA was detectable in the aqueous humour from normal cataract patients or in patients with active uveitis diagnosed as non-viral in aetiology (Behçet's disease, sarcoidosis, Harada's disease). Of the 28 patients assayed, all were seropositive for HSV, VZV, and CMV. Therefore, every clinically diagnosed viral uveitis patient with aqueous PCR positive for a herpesvirus was also seropositive for that virus, but those in the nonviral uveitis and normal groups were seropositive but PCR negative on aqueous assay. These results are consistent with results from a previous study in which $\mathrm{CMV}$, Epstein-Barr virus, and HSV-1 DNA sequences were not detected in aqueous specimens from normal donors despite serological evidence of previous exposure to these herpesviruses. ${ }^{9}$

Our study suggests that herpesviruses may play a role in the pathogenesis of uveitis of unknown aetiology. It is known that HSV or VZV may cause either anterior or posterior uveitis. Recurrent iridocyclitis induced by either virus may occur in the absence of overt herpetic ocular disease such as dendritic or immune keratitis, thus making diagnosis difficult. $^{23}$ Similarly, CMV may cause posterior uveitis, which may be difficult to distinguish from retinitis resulting from $\mathrm{HSV}$ or $\mathrm{VZV} .^{22}$ Complex interactions between the virus and host immune system seem to play a key role in determining the clinical expression of these ocular inflammatory conditions. In the absence of other uveitis aetiological factors such as collagen vascular disease, the index of suspicion of herpesvirus should be raised regardless of the patient's immune status.

PCR detection of a specific viral DNA supports a specific clinical diagnosis and has therapeutic implications. In the present study, HSV DNA was detected in five patients (cases 3-7, Table 2) with recurrent episodes of unilateral iridocyclitis, mild IOP increases, and pigmented keratic precipitates. These five patients responded to treatment with oral $(1000 \mathrm{mg}$ per day for 2 weeks) or topical 3\% acyclovir ointment and corticosteroid eyedrops. Usui et al ${ }^{16}$ mainly demonstrated VZV DNA in anterior uveitis patients instead of HSV. We speculate two possible explanations for the difference between that study and ours: (1) we used the same primers for the amplification of $\mathrm{VZV}$ DNA, but the HSV primers were different from those of Usui et al, so the sensitivity of PCR for HSV was different. It is probable that our primers for HSV were more sensitive than those of Usui et al; (2) regarding anterior 
uveitis cases, Usui et al selected iritis following chickenpox, iritis with trigeminal neuralgia, and two cases of herpes zoster ophthalmicus. Therefore, they selected for VZV patients.

Among patients with clinically diagnosed ARN, one patient (case 11, Table 2) was aqueous PCR negative for all three herpesviruses. The aqueous from this patient was collected 6 months after disease onset when no inflammation was apparent and empiric treatment with acyclovir had been completed 3 months before. It is possible that in the late stage of ARN, few or no infected cells remain in the aqueous humour specimens. ${ }^{17}$

The CMV genome was detected in one case of chorioretinitis in a patient with malignant lymphoma (case 8, Table 2). In this case, we detected CMV specific DNA in 1 day and ganciclovir therapy was initiated based on the PCR results.

VZV DNA was detected in one case of iridocyclitis (case 9, Table 2). This patient had no dermatitis and her cornea was normal, making diagnosis difficult. The case was determined to be one of zoster sine herpete by aqueous PCR assay. ${ }^{23}$ This patient was treated successfully with high dose acyclovir (800 mg five times daily for 2 weeks) plus gamma globulin $(2 \cdot 5$ g/day for 5 days).

Except for one case (case 8), patients in this study were basically healthy and immunocompetent. Yet, we detected herpesvirus DNA in the aqueous humour of those with suspected viral aetiology of disease. This may result from the incidental shedding of herpesvirus into the aqueous humour that was unrelated to the disease, or from reactivated virus inciting inflammation. However, the former is not likely, because no amplification of herpesvirus DNA was demonstrable in the aqueous humour in the patients with other types of uveitis and in patients undergoing cataract surgery. Moreover, our herpesvirus suspect patients responded to the use of topically applied or systemically administered acyclovir.

In this study, we investigated a PCR assay for detecting herpesvirus DNA in the aqueous humour of 18 patients with uveitis, 11 of suspected viral aetiology, and seven with other established aetiologies. The PCR results were well matched with the clinical diagnoses, indicating that PCR is a useful and rapid diagnostic tool for supporting clinical observations in uveitis.

Supported in part by Bausch \& Lomb fellowship (SY), Nippon Eye Bank Association Fellowship (SY), the Georgiana Steven Fund (DP-L), and the Nancy Johnstone Ocular Research Fund (DP-L).
1 Liesegang TJ. Diagnosis and therapy of herpes zoster ophthalmicus. Ophthalmology 1991; 98: 1216-29.

2 Pavan-Langston D, Brockhurst R. Herpes simplex panuveitis. Arch Ophthalmol 1969; 81: 783-7.

3 Pavan-Langston D. Viral disease of the cornea and external eye. In: Albert DM, Jakobiec FA, eds. Principles and practice of ophthalmology. Vol 1. Philadelphia: W B Saunders, 1994: 117-61.

4 Gartry DS, Spalton DJ, Tilzey A, Hykin PG. Acute retinal necrosis syndrome. $\mathrm{Br} \mathcal{F}$ Ophthalmol 1991; 75: 292-7.

5 Freeman WR, Thomas EL, Rao NA, Pepose JS, Trousdale $\mathrm{MD}$, Howes EL, et al. Demonstration of herpes group virus in acute retinal necrosis syndrome. Am $\mathcal{f}$ Ophthalmol 1986; 102: 701-9.

6 Culbertson WW, Blumenkranz MS, Pepose JS, Stewart JA, Curtin VT. Varicella zoster is a cause of the acute retinal necrosis syndrome. Ophthalmology 1986; 93: 559-69.

7 de Bore JH, Luyendijk L, Rothova A, Baarsma GS, de Jong PTVM, Bollemeijer JG, et al. Detection of intraocular antibody production to herpesviruses in acute retinal necrosis syndrome. Am 7 Ophthalmol 1994; 117: 201-10.

8 Pepose JS, Flowers B, Stewart JA, Grose C, Levy GS, Culbertson WW, et al. Herpesvirus antibody levels in the etiologic diagnosis of the acute retinal necrosis syndrome. Am F Ophthalmol 1992; 113: 248-56.

9 Fox GM, Crouse CA, Chuang EL, Pflugfelder SC, Cleary TJ, Nelson SJ, et al. Detection of herpesvirus DNA in vitreous and aqueous specimens by the polymerase chain veaction. Arch Ophthalmol 1991; 109: 266-71.

10 Cao M, Xiao X, Egbert B, Darragh TM, Benedict Yen TS. Rapid detection of cutaneous herpes simplex virus infection with the polymerase chain reaction. $\mathcal{F}$ Invest Dermatol tion with the polym

11 Ohashi Y, Yamamoto S, Nishida K, Okamoto S, Kinoshita $S$, Hayashi $K$, et al. Demonstration of herpes simplex virus DNA in idiopathic corneal endotheliopathy. $A m$ f Ophthalmol 1991; 112: 419-23.

12 Yamamoto S, Shimomura Y, Kinoshita S, Nishida $\mathrm{K}$, Yamamoto R, Tano Y. Detection of herpes simplex virus DNA in human tear film by the polymerase chain reaction. Am $\mathcal{F}$ Ophthalmol 1994; 117: 160-3.

13 Yamamoto S, Shimomura Y, Kinoshita S, Tano Y. Differentiating zosteriform herpes simplex from ophthalmic zoster. Arch Ophthalmol 1994; 112: 1515-6.

14 Alvarado JA, Underwood JL, Green WR, Wu S, Murphy CG, Hwang DG, et al. Detection of herpes simplex viral DNA in iridocorneal endothelial syndrome. Arch Ophthalmol 1994; 112: 1601-9.

15 Yamamoto S, Pavan-Langston D, Tada R, Yamamoto R, Kinoshita S, Nishida $K$, et al. Possible role of herpes simplex virus in the origin of Posner-Schlossman syndrome. Am $₹$ Ophthalmol 1995; 119: 796-8.

16 Usui M, Usui N, Goto H, Minoda H, Rai T. Polymerase chain reaction for diagnosis of herpetic intraocular inflammation. Ocular Immunol Inflammation 1993; 1: 105-12.

17 Nishi M, Hanashiro R, Mori S, Masuda K, Mochizuki M, Hondo R. Polymerase chain reaction for the detection of the varicella-zoster genome in ocular samples from patients with acute retinal necrosis. Am $\mathcal{f}$ Ophthalmol 1992; 114: 603-9.

18 Demmler GJ, Buffone GJ, Schimbor CM, May RA. Detection of cytomegalovirus in urine from newborns by using polymerase chain reaction DNA amplification. using polymerase chain reaction

19 Biswas J, Mayr AJ, Martin WJ, Rao NA. Detection of human cytomegalovirus in ocular tissue by polymerase chain reaction and in situ DNA hybridization. Graefes Arch Clin Exp Ophthalmol 1993; 231: 66-70.

20 Mullis K, Faloona F, Scharf S, Saiki R, Horn G, Erlich H. Specific enzymatic amplification of DNA in vitro: the polymerase chain reaction. Symp Quant Biol 1986; 51: 263-73.

21 Saiki RK, Scharf S, Faloona F, Mullis KB, Horn GT, Erlich HA, et al. Enzymatic amplification of $\beta$-globin genomic sequences and restriction site analysis for diagnosis of sickle cell anemia. Science 1985; 230: $1350-4$.

22 Nussenblatt R, Palestine A. Uveitis: fundamentals and clinical practice. Chicago: Year Book Medical Publishers, 1989: 416-30.

23 Easton HG. Zoster sine herpete causing acute trigeminal neuralgia. Lancet 1970; 2: 1065-6. 